\title{
SI-PAKARDI (Sistem Pakar Diagnosa Penyakit Gigi) Menggunakan Metode Forward Chaining
}

\author{
Andrian Eko Widodo ${ }^{1}$, Suleman ${ }^{2}$, Angga Ardiansyah ${ }^{3}$, Dany Pratmanto ${ }^{4}$, \\ Sopian Aji ${ }^{5}$, Dhea Savitri ${ }^{6}$ \\ ${ }^{1,6}$ Teknologi Komputer, Universitas Bina Sarana Informatika \\ Indonesia \\ ${ }^{2,3,4,5}$ Sistem Informasi, STMIK Nusa Mandiri Jakarta \\ Indonesia \\ Email:'suleman.sln@bsi.ac.id, 2andrian.aeo@nusamandiri.ac.id,

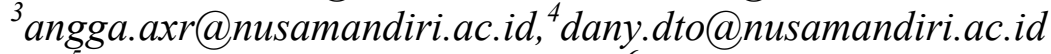 \\ sopian.sop@nusamandiri.ac.id, ${ }^{6}$ dheaku.91@bsi.ac.id
}

\begin{abstract}
The lack of knowledge about dental health and the still limited awareness of the community about dental health, makes some of our community set aside in efforts to prevent or treat dental disease. So we need a system or application that can help people to find out about dental diseases, as well as solutions to overcome these problems. This expert system knowledge base is formed by the if-then rules. The inference method used is forward chaining. This dental disease expert system is based on Android so it can be used anytime and anywhere by the community. Based on the acquisition of expert knowledge obtained 12 rules, 12 diseases, 25 symptoms. Blackbox test results show the application features that are made to run with a fairly good level of success. Unit test results indicate that the application has succeeded in making inferences properly and correctly, in accordance with applicable rules.
\end{abstract}

Keywords: Dental disease, forward chaining, android, expert system

\begin{abstract}
Abstrak
Minimnya pengetahuan kesehatan gigi dan masih terbatasnya kesadaran masyarakat tentang kesehatan gigi, membuat sebagian masyarakat kita mengesampingkan dalam upaya mencegah atau mengobati penyakit gigi. Maka diperlukan suatu sistem atau aplikasi yang dapat membantu masyarakat untuk mengetahui tentang penyakit gigi, serta solusi untuk mengatasi permasalahan tersebut. Basis pengetahuan sistem pakar ini dibentuk dengan aturan if-then. Metode inferensi yang digunakan adalah forward chaining. Sistem pakar penyakit gigi ini dibuat berbasis android agar bisa digunakan kapan saja dan dimana saja oleh masyarakat. Berdasarkan akusisi pengetahuan pakar didapat 12 aturan, 12 penyakit, 25 gejala. Hasil uji blackbox menunjukan fitur-fitur aplikasi yang dibuat berjalan dengan tingkat berhasilan yang cukup baik. Hasil unit test menunjukkan bahwa aplikasi telah berhasil melakukan inferensi dengan baik dan benar, sesuai kaidah yang berlaku.
\end{abstract}

Kata kunci: Penyakit gigi, forward chaining, android, sistem pakar 


\section{A. PENDAHULUAN}

Teknologi komputer semakin berkembang pada era yang kita kenal dengan zaman millenal,sebagian besar pekerjaan telah melibatkan teknologi komputer, tidak hanya menjadi alat bantu hitung seperti penggunaan awal komputer tapi juga menjadi alat bantu penyelesaian masalah-masalah yang dihadapi manusia. Salah satu cabang ilmu teknologi komputer yang bisa dimanfaatkan untuk membantu kerja manusia adalah pembentukan sistem pakar.

Menurut (Permadi, 2018) Sistem pakar adalah suatu sistem yang dirancang untuk menirukan keahlian seseorang dalam menjawab pertanyaan dan memecahkan suatu masalah. Salah satu pemanfaatan sistem pakar adalah dalam bidang kedokteran atau kesehatan. Penerapan tersebut berupa diagnosa penyakit maupun pemberian saran penentuan solusi dari hasil yang ada. Gigi merupakan organ pengunyah yang terdiri dari gigi pada rahang bawah, lidah, dan saluran-saluran penghasil air ludah, merupakan salah satu organ penting bagi kehidupan manusia, secara tidak langsung gigi berpengaruh pada kondisi kesehatan seseorang.

Minimnya pengetahuan kesehatan gigi serta terbatasnya jumlah dokter gigi menyebabkan rendahnya kesadaran masyarakat terhadap kesehatan gigi. Kondisi inilah yang membuat sebagian masyarakat mengesampingkan upaya mencegah dan mengobati penyakit gigi. Untuk mengatasi permasalahan tersebut, penelitian ini akan membahas sistem pakar untuk diagnosa penyakit gigi, sehingga masyarakat/ penderita mengetahui tentang penyakit gigi yang sedang dideritanya serta dapat mengatasi permasalahan secara dini.

Pada penelitian ini, aplikasi sistem yang dibuat berbasis mobile yang digunakan adalah Android. Aplikasi ini dibuat berbasis mobile agar aplikasi yang digunakan kapan saja dan dimana saja. Dengan adanya aplikasi mobile berbasis android ini diharapkan akan membantu masyarakat luas sebagai user dalam mencari informasi dan konsultasi pertama sebelum menindaklanjuti dengan perawatan melalui dokter gigi.

\section{B. TINJAUAN PUSTAKA}

\section{Sistem Pakar}

Menurut (Anik Andriani, 2014) dalam bukunya mengungkapkan bahwa "Sistem pakar adalah sebuah sistem yang kinerjanya mengadopsi keahlian yang dimiliki seorang pakar dalam bidang tertentu ke dalam sistem atau program komputer. 


\section{Forward Chaining}

Metode Chaining adalah teknik yang didasari dengan fakta-fakta yang diketahui, kemudian mencocokan faktafakta tersebut dengan aturan.

\section{Program}

Program dapat diartikan suatu cara dalam berfikir serta berlogika untuk menghadapi masalah-masalah yang diatasi dengan bantuan komputer. Bahasa pemograman merupakan notasi untuk memberikan perintah secara tepat program komputer.(Algoritma \& Pemrograman, 2014)

\section{Android}

Android adalah sebuah sistem operasi untuk perangkat mobile berbasis linux yang mencakup sistem operasi, middleware dan aplikasi.Android menyediakan platform terbuka bagi para pengembang untuk menciptakan aplikasi mereka.(Safaat, 2015)

\section{UML (Unified Modeling Language)}

Unified modeling languageatau UML adalah bahasa yang banyak digunakan di dunia industri untuk mendefinisikan requirement, membuat analisis dan desain, serta menggambar arsitektur dalam pemrograman berorientasi objek.(Permadi, 2018)

Berikut adalah klasifikasi diagram yang ada pada UML: a) Use Case Diagram

Use Case Diagram merupakan permodelan untuk kelakuan (behavior) sistem informasi yang akan dibuat. Use case mendeskripsikan sebuah interaksi antara satu atau lebih aktir dengan sistem informasi yang akan dibuat.(Permadi, 2018)

b) Activity Diagram

Diagram aktivitas atau activity diagram menggambarkan workflow (aliran kerja) atau aktivitas dari sebuah sistem atau proses bisnis atau menu yang ada pada perangkat lunak. (Permadi, 2018)

\section{c) Component Diagram}

Diagram komponen atau component diagram dibuat untuk menunjukan organisasi dan ketergantungan diantara kumpulan komponen dalam sebuah sistem.(Permadi, 2018)

\section{MySQL}

Menurut (Tabrani \& Pudjiarti, 2017) "MySQL adalah sebuah basis data yang mengandung satu atau lebih jumlah table.

\section{METODE PENELITIAN}

Metode penelitian yang digunakanpenulis adalahsebagai berikut : 


\section{Pengamatan (Observasi)}

Pada pengumpulan data ini melakukan survei dan pengamatan langsung sehingga dapat menyampaikan data atau informasi yang diperlukan.

\section{Wawancara (Interview)}

Selama proses pembuatan aplikasi, penulis melakukan wawancara. Wawancara dilakukan dengan tanya jawab dengan pihak dokter gigi di Klinik Pratama Aisyiyah Siti Hajar Kota Tegal untuk mendapatkan informasi yang dibutuhkan dalam proses pembuatan aplikasi.

\section{Studi Pustaka}

Pada pengumpulan data penelitian ini yaitu memelalui studi pustaka dan berbagai referensi dengan mengumpulkan data informasi dari buku dan jurnal terkait dengan pembahasan penelitian ini.

\section{HASIL DAN PEMBAHASAN}

Banyak di masyarakat kita yang pada awalnya tidak mengetahui gejala-gejala pada penyakit gigi. Bila masyarakat ingin mengetahui gejala awal tentang penyakit gigi yang dialami mereka serta cara penanganan pertama mendatangi klinik dokter gigi terdekat. Akan tetapi, tidak semua orang melakukannya, karena faktor kesibukan maupun faktor ekonomi yang kurang mendukung.

\section{1). Daftar Penyakit Gigi}

Berdasarkan penelitian dan wawancara dengan Drg. Ratna Mulyasari P.P didapat 12 penyakit dengan 25 gejala yaitu :

1. Abses Peridontal merupakan infeksi yang terletak disekitar poket poriondontal dan dapat menyebabkan kerusakan tulang rahang.

2. Abses Peripikal merupakan pembentukan nanah atau pus diujung akar gigi yang merupakan kelanjutan dari infeksi pulpa gigi bermula dari karies atau lubang yang dalam pulpa sehingga pulpa menjadi mati atau nekrosis.

3. Alveolar Osteitissama dengan $d r y$ socket adalah sakit pasca pencabutan satu sampai tiga hari yang tidak umum karena bekuan darah di lokasi bekas pencabutan gigi telah lepas sebelum luka sembuh biasanya nyeri sedang sampai berat diikuti peradangan di sekitar area bekas pencabutan.

4. Abrasis Gigi merupakan hilangnya struktur gigi akibat dari kebiasaan menyikat gigi yang terlalu keras, bagian yang terkikis adalah email (yang kita lihat secara kasat mata berwarna putih) kadang dentin yang menimbulkan rasa ngilu. 
5. Bruxism(Gigi Gemeretak) merupakan gerakan yang tidak sengaja atau reflek dalam menggerakkan gigi, menggerus gigi selama atau saat tidur yang dapat menimbukan gigi terasah atau terkikis hingga rusak dan kadang menyebabkan sakit kepala.

6. Gingivitis (Radang Gusi) merupakan radang yang terjadi pada gusi karena kurangnya perawatan atau pembersihan gigi serta mulut.

7. Gusi Bernanah merupakan radang pada gusi disertai adanya infeksi dan pembentukan nanah atau pus pada area sekitar gusi.

8. Gangguan Gigi Bungsu merupakan keadaaan dimana gigi geraham terakhir tidak dapat keluar dengan sempurna karena terhalang gigi di depannya atau kekurangan ruangan atau rahang sempit.

9. Angular Ceilitis (Radang Sudut Bibir) merupakan luka di sudut mulut atau peradangan yang terjadi karena banyak faktor seperti infeksi bakteri, virus ataupun jamur.

10. Karies Media merupakan lubang gigi yang sudah mengenai email (yang kita lihat secara kasat mata berwarna putih) dan sebagian deutin yang menyebabkan ngilu.

11. Karies Profunda merupakan lubang pada gigi yang menjalar dari email (yang kita lihat secara kasat mata berwarna putih) deutin dan bahkan menembus pulpa menimbulkan rasa sakit yang spontan.

12. Karies Superfisial merupakan lubang pada sisi yang baru mencapai daerah email (yang kita lihat secara kasat mata berwarna putih) dan jarang memberi keluhan

Tabel 1

Daftar Penyakit Gigi

\begin{tabular}{|c|l|}
\hline Id Penyalit & \multicolumn{1}{|c|}{ Nama Penyalit } \\
\hline P01 & Abses Periodontal \\
\hline P02 & Abses Peripilal \\
\hline P03 & Alveolar Osteitis \\
\hline P04 & Abrasi Gigi \\
\hline P05 & Brnxism (Gigi Gemaretak) \\
\hline P06 & Gingritis (Radang Gusi) \\
\hline P07 & Gusi Bernanah \\
\hline P08 & Gangguan Gigi Bungsu \\
\hline P09 & Angular Ceilitis (Radang Sudut Bibir) \\
\hline P010 & Karies Media \\
\hline P011 & Karies Profunda \\
\hline P012 & Karies Superfisial \\
\hline
\end{tabular}

\section{2). Nama Gejala}

Tabel 2.

Tabel Nama Gejala

\begin{tabular}{|c|l|}
\hline Id Gejala & \multicolumn{1}{|c|}{ Nama Gejala } \\
\hline G1 & Sulit mengunyah \\
\hline G2 & $\begin{array}{l}\text { Pembengkakanatau peradangan } \\
\text { pada gusi }\end{array}$ \\
\hline G3 & Gigi bergoyang \\
\hline G4 & Rahang terjadi pembengkakan \\
\hline G5 & $\begin{array}{l}\text { Pembengkakan kelenjar getah } \\
\text { bening sekitar rahang atau leher }\end{array}$ \\
\hline G6 & Demam \\
\hline G7 & Bau mulut tak sedap \\
\hline
\end{tabular}




\begin{tabular}{|c|l|}
\hline G8 & $\begin{array}{l}\text { Rasa sakit atau nyeri disekitar } \\
\text { gusi }\end{array}$ \\
\hline G9 & $\begin{array}{l}\text { Rasa sakit yang hebat selama } \\
\text { beberapa hari setelah pencabutan } \\
\text { gigi }\end{array}$ \\
\hline G10 & Tulang terlihat pada socket gigi \\
\hline G11 & Gigi terasa ngilu dan sensitive \\
\hline G12 & Bentuk gigi tampak terkikis \\
\hline G13 & Bintik putih pada gigi \\
\hline G14 & Insomnia atau merasa gelisah \\
\hline G15 & $\begin{array}{l}\text { Suara gemeretak gigi } \\
\text { terdengar ketika tidur }\end{array}$ \\
\hline G16 & Gusi mudah berdarah \\
\hline G17 & Bentuk gusi agak membulat \\
\hline G18 & Sakit kepala \\
\hline G19 & Gusi atau gigi bernanah \\
\hline G20 & $\begin{array}{l}\text { Kemerahan pada } \\
\text { mulut }\end{array}$ \\
\hline G21 & Sudut mulut terasa nyeri \\
\hline G22 & Sudut mulut bersisik \\
\hline G23 & Gigi terasa berdenyut \\
\hline G24 & Ulkus (luka pada sudut mulut) \\
\hline G25 & Gigi berlubang \\
\hline
\end{tabular}

\section{3). Rule Pada Pakar}

Untuk pengetahuan dan mendapat solusi terbaik dari beberapa masalah penyakit gigi, maka penulis membuat knowledge base atau rule base sistem pakar yang biasanya ditulis dalam bentuk

Tabel 3. Tabel Rule

\begin{tabular}{|c|l|c|}
\hline Rule & \multicolumn{1}{|c|}{$I F$} & $T H E N$ \\
\hline 1 & G1\&G2\&G3 & P1\&S1 \\
\hline 2 & $\begin{array}{l}\text { G1\&G4\&G5\&G6\&G7\&G } \\
8\end{array}$ & P2\&S1 \\
\hline 3 & G7\&G9\&G10 & P3\&S4 \\
\hline 4 & G11\&G12 & P4\&S6 \\
\hline 5 & G14\&G18\&G25 & P5\&S1\&S2 \\
\hline 6 & G5\&G16\&G17 & P6\&S1 \\
\hline 7 & G2\&G5\&G6\&G19\&G23 & P7\&S3 \\
\hline 8 & G1\&G2\&G4\&G7\&G8 & P8\&S4 \\
\hline 9 & G20\&G21\&G22\&G24 & P9\&S5 \\
\hline 10 & G11\&G25 & P10\&S6 \\
\hline 11 & G23\&G25 & P11\&S6 \\
\hline 12 & G13\&25 & P12\&S1\&S6 \\
\hline
\end{tabular}

jika-maka (IF-THEN) adalah sebagai berikut:

\section{Keterangan Rule:}

\section{Rule 1 :}

Jika Pembengkakan atau peradangan pada gusi dan sulit mengunyah dan gigi bergoyang maka penderita mengalami Abses Periodontal dan solusi penanganannya dengan pemberian antiobiotik

\section{Rule2 :}

Jika bau mulut tak sedap dan sulit mengunyah dan rahang terjadi pembengkakan dan rasa sakit atau nyeri di sekitar gusi dan demam dan pembengkakan kelenjar getah bening sekitar rahang atau leher maka penderita mengalami Abses Peripikal dan solusi penangananya dengan pemberian antibiotic

\section{Rule3 :}

Jika bau mulut tak sedap dan rasa sakit yang hebat selama beberapa hari pencabutan gigi dan tulang terlihat pada Socket maka penderita mengalami Alveolar Osteitis dan solusi penanganannya dengan pencabutan gigi.

\section{Rule 4:}

Jika gigi terasa ngilu dan sensitif dan bentuk gigi tampak terkikis maka penderita mengalami Abrasi Gigi dan solusi penangananya dengan penambalan gigi 


\section{Rule5 :}

Jika gigi terasa ngilu dan sensitif dan sakit kepala dan insomnia atau merasa gelisah dan suara gemeretak gigi yang terdengar ketika tidur maka penderita mengalami Bruxism (Gigi Gemeretak) solusi penangananya dengan pemberian antibiotik dan menggunakan night guard (pelindung gigi) saat tidur

Rule 6: Jika pembengkakan atau peradangan pada gusi dan gusi mudah berdarah dan bentuk gusi agak membulat dan konsistensi gusi menjadi lunak maka penderita mengalami Gingvitis (Radang Gigi) dan solusi penanganannya dengan pemberian antibiotik

Rule 7: Jika pembengkakan atau peradangan pada gusi dan demam dan pembengkakan kelenjar getah bening sekitar rahang atau leher dan gusi atau gigi bernanah dan gigi terasa sakit atau berdenyut maka penderita mengalami Gusi Bernanah dan solusi penanganannya dengan pemberian antibiotik, membalut luka.

Rule 8: Jika bau mulut tak sedap dan sulit menguyah dan rahang terjadi pembengkakan dan rasa sakit atau nyeri di sekitar gusi dan pembengkakan atau peradangan pada gusi maka penderita mengalami Gangguan Gigi Bungsu dan solusi penanganannya dengan pencabutan gigi bungsu.
Rule 9: Jika kemerahan pada sudut-sudut mulut dan sudut mulut terasa nyeri dan sudut mulut bersisik dan ulkus (luka pada sudut mulut) maka penderita mengalami Angular Ceilitis (Radang Sudut Bibir) dan solusi penangannya dengan menggunakan obat anti jamur

Rule 10: Jika gigi berlubang dan gigi terasa ngilu dan sensitif maka penderita mengalami Karies Media dan solusi penangananya dengan penambalan gigi.

Rule 11: Jika gigi berlubang dan pulpa terinfeksi/radang pada pulpa dan sakit berdenyut maka penderita mengalami Karies Profunda dan solusi penanganannya dengan penambalan gigi.

Rule 12: Jika gigi berlubang dan bintik putih pada gigi maka penderita mengalami Karies Superfisial dan solusi penanganannya dengan pemberian antibiotik dan penambalan gigi.

\section{4). Flowchart}

Berikut penulis gambarkan flowchart dari aplikasi SI-PAKARDI: 


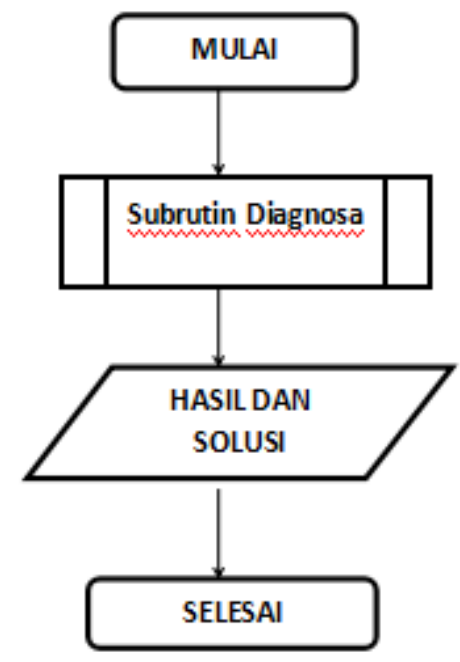

Gambar 1.

Diagram Alur Diagnosa Penyakit Gigi

\section{5). Rancangan Antar Muka si-pakardi}

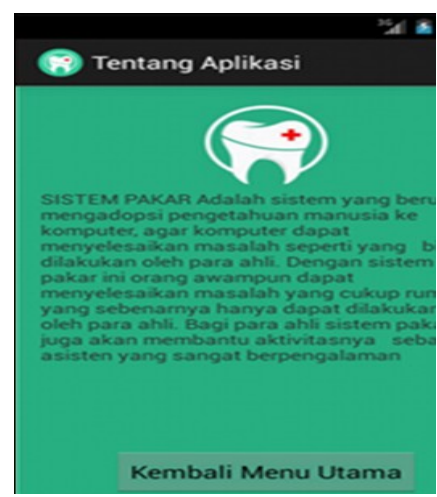

Gambar 2. Tampilan Aplikasi

Rancangan antar muka bagian back end yaitu rancangan yang digunakan oleh bagian admin, yaitu halaman beranda pada halaman beranda menampilkan awal dari halaman admin. Pada halaman beranda terdapat menu about menampilkan informasi tentang aplikasi.

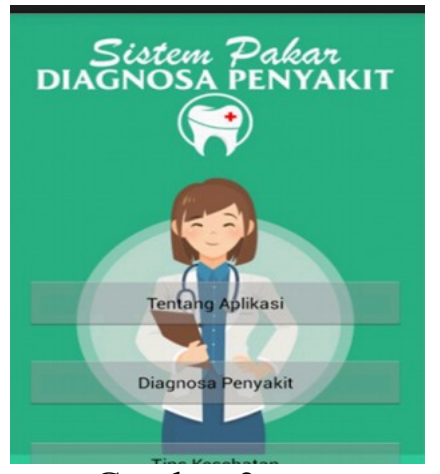

Gambar 3.

Tampilan Awal Si-Pakardi

Halaman home terdapat menu konsultasi untuk melakukan diagnosa penyakit gigi, menu informasi tentang penyakit gigi, menu next untuk melanjutkan aplikasi.

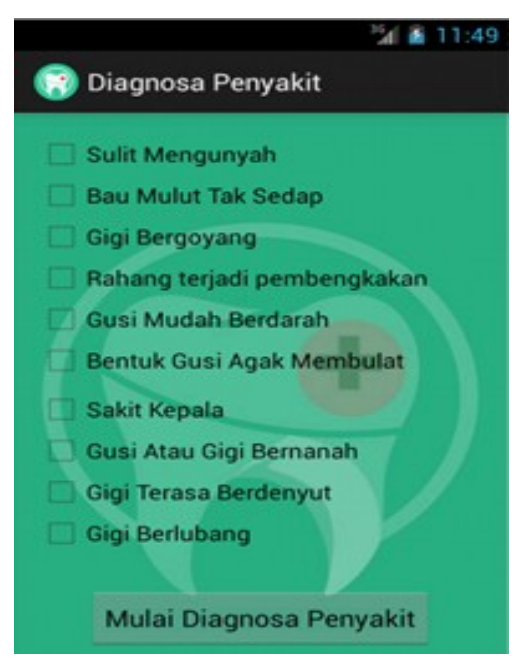

\section{Gambar 4.}

Tampilan Menu Diagnosa

Dalam menu diagnosa user bisa melakukan pilihan untuk mendignosa penyakit gigi dari aplikasi ini. 


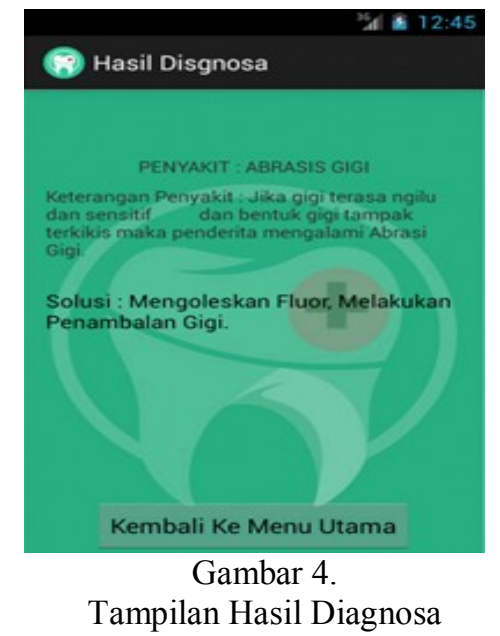

Dalam menu hasil diagnosa user dapat mengetahui hasil diagnosa yang dipilihnya sebelumnya serta akan diberikan informasi tentang nama penyakit, solusi dan gejalanya dari sistem ini.

\section{E. KESIMPULAN}

Dari hasil keseluruhan rancangan aplikasi sistem pakar diagnosa penyakit gigidapat disimpulkan bahwa (1). Aplikasi Sistem pakar ini dibuat untuk mengetahui secara dini penyakit gigi yang sedang dialami sehingga pengguna dapat mengetahui solusi dari penyakit tersebut. (2). Aplikasi Sistem Pakar ini dapat digunakan untuk mempercepat pencarian dan pengaksesan terhadap ilmu pengetahuan oleh orang yang membutuhkan informasi tentang penyakit gigi. (3). Implementasi sistem melakukan kesimpulan berdasarkan pada fakta yang ada dengan metode Forward Chaining. (4). Keluaran Sistem pakar ini berupa info atau keterangan berupa nama penyakit, dan solusi penyakit. (5). Aplikasi sistem pakar ini diharapkan menjadi solusi alternative pemecahan masalah bagi masyarakat dalam hal penanganan penyakit gigi.

\section{DAFTAR PUSTAKA}

[1] Algoritma, P., \& Pemrograman, D. A. N. (n.d.). Pengantar algoritma dan pemrograman. (0644), 72-79.

[2] Anik Andriani, M. ko. (2014). Pemrograman sistem pakar. Yogyakarta.

[3] Arifin, J. (2016). Sistem Pakar Diagnosa Penyakit Gigi dan MulutManusia Menggunakan Knowledge Base System dan Certainty Factor. 10(2), 50-64.

[4] Ayu, F., \& Permatasari, N. (2016). perancangan sistem informasi pengolahan data PKL pada divisi humas PT pegadaian. Jurnal Infra Tech, 2(2), 12-26. Retrieved from http://journal.amikmahaputra.ac.id/in dex.php/JIT/article/download/33/25

[5] Bahat, S., \& Anthoni, N. (2017). SISTEM PAKAR MENDIAGNOSA PENYAKIT GIGI DAN MULUT DENGAN MENGGUNAKAN. 141146.

[6] Bangun, R., Informasi, S., Dan, P., Jasa, R., Pada, M., \& Surabaya, S. B. (2014). Jurnal Sistem Informasi. 3(1).

[7] Leonardo, H. (2017). SISTEM PAKAR MENDIAGNOSIS PENYAKIT MULUT DAN GIGI BERBASIS ANDROID DENGAN METODE BACKWARD CHAINING. 2(1), 1-6.

[9] Maiyana, E., Informatika, M., By, J., \& Simpang, P. (2018). PEMANFAATAN ANDROID. 1, 54- 
67.

[10] Permadi, D. (2018). SISTEM PAKAR DIAGNOSA PENYAKIT GIGI DAN MULUT. 5(1).

[11] Prayitno, A., \& Safitri, Y. (2015). Pemanfaatan Sistem Infromasi Perpustakaan Digital Berbasis Website Untuk Para Penulis. IJSE Indonesian Journal on Software Engineering, 1(1), 1-10. https://doi.org/10.4028/www.scientifi c.net/AMR.756-759.138

[12] Raharjo, J. S. D., Damiyana, D., \& Irvansyah, R. (2018). Aplikasi Sistem Pakar untuk Diagnosa Penyakit Gigi dan Mulut Menggunakan Metode Forward Chaining Berbasis Android. $8(2)$.

[13] Rezky, S. F. (2017). Sistem Pakar Gigi dan Mulut Menggunakan Aplikasi Android Studio Metode Forward Chaining. 229-233.

[14] Sopingi. (2016). Kata Kunci: Donasi, Hybrid Mobile, Web Service, SOA. Sistem Informasi Donasi Berbasis Hybrid Mobile Menggunakan Web Service Pada Yayasan Solo Peduli, 10(April), 1-17.

[15] Tabrani, M., \& Pudjiarti, E. (2017). Penerapan Metode Waterfall Pada Sistem Informasi Inventori Pt. Pangan Sehat Sejahtera. Jurnal Inkofar, 1(2), 30-40.

[16] Tangerang, D. I. K., Ramadhan, T., Utomo, V., Polanda, D., Watrianthos, R., Purnama, I., ... Fisika, P. P. (2018). Aplikasi Komputer dan Smartphone Berbasis Android untuk Menangani Reservasi Hotel pada Citi Smart Hotel - BSD. Jurnal Pendidikan Islam, 5(2), 2. https://doi.org/10.31294/jtk.v4i2.359 7
[17] Yulianti, R. (2014). Perawatan Ortodonti. 8-42. 